\title{
BIMBINGAN KONSELING DAN IMPLEMENTASINYA (MASALAH DALAM PRAKTEK BIMBINGAN KONSELING DI ERA DIGITAL DAN BAGAIMANA MENGATASINYA?)
}

\author{
Muhammad Subhan', Neviyarni Suhailii' ${ }^{2 a}$, Mudjiran ${ }^{2 b}$, Herman Nirwana $^{2 c}$ \\ ${ }^{1}$ Fakultas MIPA, Universitas Negeri Padang \\ email: 13subhan@fmipa.unp.ac.id \\ ${ }^{2}$ Fakultas Ilmu Pendidikan, Universitas Negeri Padang \\ email: aneviyarni.suhaili11@gmail.com \\ bmudjiran.unp@gmail.com \\ cherman.nirwana@yahoo.com
}

\begin{abstract}
This article discuss about the obstacles faced by counselor in digital era. Method using in this research is systematic review. Some research show that even if counselors have personality competence, then theirs professionalism are not adequate. In the era of digital information and technology, the attitude and personality of student have change because they use technology more. Development of counseling training and conducting researches about effectiveness of cyber counseling are needed to improve the guidance and also counseling processes.

Keywords: counsellor's personality and competency, guidance and counselling, digital
\end{abstract}

\begin{abstract}
Abstrak
Kajian ini ditujukan untuk memaparkan kendala yang dialami konselor dalam tugasnya memberikan pelayanan di era digital. Metode yang digunakan adalah systematic review dengan teknik kualitatif. Beberapa penelitian menunjukkan bahwa konselor sudah memiliki kompetensi kepribadian yang diharapkan namun untuk profesionalitas yang belum memadai. Kompetensi ini menjadi sangat penting untuk ditingkatkan karena perkembangan teknologi dan informasi. Era digital membawa perubahan pada peserta didik baik dalam tingkah laku maupun kepribadian karena mereka lebih banyak menggunakan teknologi. Pengembangan pelatihan layanan konseling dan penelitian terkait efektivitas konseling digital sangat dibutuhkan untuk peningkatan proses bimbingan dan juga konseling.
\end{abstract}

Kata Kunci: bimbingan dan konseling, kepribadian dan kompetensi konselor, digital.

\section{PENDAHULUAN}

Salah satu faktor penunjang keberhasilan pencapaian tujuan pendidikan di sekolah adalah layanan Bimbingan Konseling (BK). Pada dasarnya, BK dilaksanakan untuk membantu peserta didik mengoptimalkan pengembangan potensi dirinya dan mendorong mereka agar dapat mencapai tugas-tugas perkembangannya[1]. Implikasinya, BK diharapkan membantu peserta didik untuk mengatasi permasalahan-permasalahan yang dapat menghambat pengembangan bakat yang dimiliki serta hal-hal yang membuat mereka tidak 
dapat menjalani tugas perkembangannya. Tugas-tugas perkembangan yang terhambat akan menimbulkan kendala di tahap perkembangan selanjutnya.

Untuk dapat melakukan pelayanan BK yang optimal, pemerintah memberikan ketentuan melalui beberapa peraturan terkait siapa dan kompetensi apa yang musti dimiliki oleh pendidik di lingkungan pendidikan. Permendiknas No. 27 tahun 2008, Pasal 1 ayat 1 menjelaskan bahwa seseorang dianggap sudah mampu menjadi konselor apabila sudah memenuhi standar yang ditetapkan secara nasional terkait kualifikasi secara akademik dan kompetensi sebagai konselor. Ini berarti seseorang musti memiliki pengetahuan dan keterampilan yang memenuhi standar agar bisa melakukan layanan BK. Di sisi lain, kebutuhan layanan BK dengan ketersediaan guru BK yang sesuai ketentuan tidak seimbang. Oleh karena itu, pemerintah melalui Peraturan Pemerintah No. 74 tahun 2008 mendorong pendidik dari latar belakang pendidikan lain untuk memiliki dasar kemampuan pelayanan BK dengan mensyaratkan pemberian tunjangan profesi jika sudah memiliki sertifikat dan melakukan bimbingan dan konseling.

Asosiasi Bimbingan dan Konseling Indonesia (ABKIN) telah menetapkan seorang konselor mustilah mempunyai karakteristik dan kemampuan tertentu, yaitu 1) memiliki nilai, sikap, keterampilan, pengetahuan dan wawasan di bidang profesi konseling, dan 2) adanya pengakuan atas kemampuan dan kewenangan sebagai seorang konselor[2]. Dari sudut pandang personal, seorang konselor seharusnya memiliki sifat-sifat jujur, rendah hati, sederhana, dapat dipercaya, sabar, tepat waktu dan janji, serta menghargai orang lain. Konselor harus mampu memahami dirinya, baik kelebihan dan kelemahannya sebagai pribadi maupun konselor dalam melakukan pelayanan. Dari sudut pandang profesionalitas, konselor harus memiliki sikap kerja yang bertanggung jawab, profesional dan mampu bekerja sama dengan rekan sesama profesi, mampu berpikir ilmiah dalam memahami dan mengeksplorasi permasalahan yang diajukan, serta menguasai teknik-teknik dan prosedur konseling yang sesuai dengan kaidah ilmiah[3,4]. Di sisi lain ada beberapa kompetensi dan pengetahuan yang penting dimiliki, yaitu kompetensi multikultural yang merupakan pemahaman akan asumsi budaya dan etnis, norma-norma, dan bias dari berbagai identitas budaya dan ras[5]. Kompetensi ini akan membantu dalam menjunjung tinggi nilai-nilai kebebasan memilih, individualitaas, dan kemanusiaan[4]. Konselor juga harus punya pengetahuan tentang perkembangan fisiologis dan psikologis peserta didik, serta permasalahan-permasalahan yang umum dialami mereka terkait dengan perkembangan tersebut.

Dalam pelaksanaan layanan BK, ada interaksi antara konselor dan peserta didik yang menentukan tercapai atau tidaknya tujuan layanan yang diharapkan. Motivasi peserta didik untuk mau menjalani konseling sangat ditentukan oleh kepribadian dan kompetensi profesional konselor[4]. kepribadian konselor yang diinginkan oleh peserta didik adalah memiliki keyakinan akan Tuhan, mengutamakan nilai kemanusiaan, respek terhadap individualitas dan kebebasan memilih, memiliki integritas yang tinggi, karakter yang kuat, dan kepribadian yang stabil, serta mampu memperlihatkan performa yang berkualitas[6]. Dari penjelasan ini, terlihat adanya sejumlah persamaan kriteria antara kompetensi profesional dan kompetensi kepribadian berdasarkan ketentuan formal dengan persepsi peserta didik yang menerima layanan BK. Tujuan penelitian ini adalah untuk melihat permasalahan dari sisi konselor dikaitkan dengan era digital. 


\section{METODOLOGI}

Metode penelitian yang digunakan adalah systematic review dengan teknik kualitatif. Artikel ilmiah dikumpulkan dari database google scholar dan crossreference dengan menggunakan program Harzing's Publish or Perish (Windows GUI Edition) 7.27. 2949.7581. Adapun artikel yang dianalisa merupakan terbitan dari tahun 2006 sampai dengan 2021. Adapun kata kunci untuk mengumpulkannya adalah konselor, kepribadian, kompetensi, permasalahan, dan digital.

\section{HASIL PENELITIAN DAN PEMBAHASAN}

Dari hasil seleksi diperoleh 9 artikel yang sesuai dengan tujuan penelitian, yaitu 7 tentang kompetensi dan kepribadian konselor dan 2 tentang digital.

1. Permasalahan Mengenai Kompetensi Guru BK di Sekolah

Adanya standarisasi pendidikan dan kompetensi yang harus dicapai oleh guru BK tidak seiring dengan implementasi di lapangan. Hasil uji kompetensi konselor kurang menguasai kompetensi teoritik terkait dengan teori, prinsip dan prosedur BK, teknik BK yang memberdayakan, serta kurang dorongan untuk terus mengembangkan kompetensinya[7]. Di sisi lain, dari aspek kepribadian, konselor sudah menampilkan sikap, nilai dan kepribadian seperti yang diharapkan[7]. Sementara diketahui sebanyak 50-74\% konselor telah memahami etika profesional, menguasai kompotensi profesional, menguasai dengan baik konsep dan praksis penilaian untuk memahami kebutuhan, kondisi, dan permasalahan peserta didik, menguasai konsep dan praksis BK, serta kompeten dalam mengimplementasikan program BK [8]. Walaupun demikian, diketahui juga bahwa konselor masih kurang mampu dalam merancang program konseling, mengevaluasi proses konseling, serta mengembangkan penelitian[8]. Kedua hasil penelitian ini memperlihatkan bahwa permasalahan yang penting disorot terkait kompetensi guru BK adalah kompetensi profesionalitas, terutama dalam kemampuan berpikir ilmiah, sistematis dan komprehensif dalam memahami permasalahan peserta didik, menjalankan prosedur dan teknik konseling yang sesuai, serta melakukan evaluasi dan riset mengenai proses konseling yang dilakukan.

\section{Permasalahan Berkaitan dengan Peserta Didik}

Era digital memberikan perubahan dalam berbagai lini kehidupan masyarakat, yang dengan sendirinya juga menimbulkan terjadinya perubahan tingkah laku. Generasi muda saat ini juga dikenal sebagai generasi digital yang dalam kesehariannya tidak bisa dilepaskan dengan teknologi informasi dan komunikasi, seperti internet dan gawai. Internet sudah menjadi bagian kehidupan mereka, sebagai sarana untuk komunikasi sampai skala global, akses informasi, dan hiburan[9]. Kemajuan ini memberikan perubahan dalam aspek pribadi mereka menjadi generasi yang mudah menggunakan dan dimudahkan semua kegiatan dengan teknologi, terbuka dengan perubahan, percaya diri, mudah dan banyak memperoleh informasi (terutama melalui internet), kurang sabar, mudah beradaptasi, mudah mengalami tekanan, berorientasi tim, serta sangat memperhatikan penampilan diri[10]. 
Dengan kemajuan teknologi, pola relasi juga mengalami perubahan. Peserta didik mampu menjalin pertemanan tanpa ada batas ruang dan jarak, sehingga mereka dapat saja mengindentifikasi teman sebaya dari berbagai tempat dan dapat memilih teman sesuai dengan kebutuhannya[11]. Melalui media sosial, mereka dapat menjalin relasi pertemanan dengan siapa saja. Hal ini memberikan konsekuensi positif dan negatif. Survei American Psychologist Association (APA) tahun 2017 terhadap 3.458 generasi Z yang berusia 15-21 tahun, ditemukan bahwa mereka merasa media sosial sudah menjadi bagian hidupnya dan mereka memperoleh dukungan emosi dari mengaksesnya namun $45 \%$ merasa dihakimi dan $38 \%$ responden merasakan emosi negatif ketika menggunakan sosial media[12]

Permasalahan psikologis yang muncul dengan akses internet ini sangat beragam, meliputi adiksi internet dan media sosial, adiksi game-online, cyberbullying, adiksi pornografi, depresi, anxietas dll. Hasil meta-analisa terhadap 15 artikel ilmiah menunjukkan umpan balik negatif, merasa dikucilkan, sikap pasif dapat menurunkan mood, life satisfaction, subjective well-being dan selfesteem[13]. Selain itu, aspek pola pikir mengalami perubahan tergantung dengan informasi yang mereka terima. Algoritma dan penggunaan big data di internet dapat memperkuat pola pikir seseorang menjadi lebih radikal karena mereka akan selalu diberikan informasi yang sejenis sesuai dengan topik yang sering mereka akses[14].

Dengan adanya perubahan diatas, menjadi tantangan bagi konselor dalam menjalankan tugasnya membantu peserta didik menemukan solusi dari permasalahannya dan mengembangkan dirinya secara optimal. Mungkin saja pengetahuan dan keterampilan yang dipelajari atau dikuasai konselor saat ini belum mumpuni dalam memberikan pelayanan sebagaimana yang diinginkan dan dibutuhkan peserta didik.

3. Strategi Mengatasi Permasalahan terkait Kompetensi Konselor dan Perubahan Generasi

Kompetensi profesional yang masih perlu dikembangkan lagi berdasarkan penjabaran diatas adalah pola pikir ilmiah dalam memahami permasalahan dan menyusun rencana konseling atau program yang tepat, serta mampu menggunakan teknik dan prosedur yang sesuai, serta melakukan evaluasi dan riset mengenai proses konseling yang dilakukan. Fokus utama dalam mengatasinya adalah melakukan perubahan pola pikir konselor. Mereka harus mampu menunjukkan perilaku yang cerdas, produktif, kreatif, dan inovatif. Konselor sebaiknya merubah dirinya dari menghafal teori kompetensi dan menggantinya dengan tindakan dari hati, dari sekedar ikut pelatihan menjadi terlibat secara aktif, dari budaya pembelajar instan berubah menjadi pembelajar proses serta berani dan kreatif berpikir out of the box atau di luar apa yang biasa terpikirkan oleh orang-orang umumnya [15].

Kemajuan teknologi dapat menjadi peluang dan tantangan bagi konselor untuk mengembangkan model konseling yang dapat diterima oleh peserta didik generasi digital saat ini. Peserta didik mungkin akan lebih nyaman menjalani proses bimbingan dan konseling dengan menggunakan media internet. Layanan digital melalui media sosial memiliki karakteristik tidak terbatas oleh ruang dan waktu, serta menjamin kerasahasiaan yang lebih 
baik dalam pelayanan dan referensi maksimal[10]. Saat ini, terobosan yang inovatif dalam bentuk pelayanan cyber counseling telah digunakan dalam dunia konseling bagi generasi digital yang dikenal juga dengan generasi $\mathrm{Z}$. Beberapa metode cyber counseling yang telah digunakan oleh konselor, antara lain: cyber counseling berbasis surat elektronik atau e-mail, cyber counseling chat-asynchronous berbasis android, cyber counseling berbasis teks menggunakan riliv aplikasi android, dan cyber counseling berbasis media sosial Facebook[16].

Konselor juga perlu menambah wawasannya terkait keunikan generasi digital saat ini. Oleh karena itu membaca literatur terbaru tentang penelitian dampak internet bagi remaja menjadi penting. Pengetahuan ini diharapkan menjadikan konselor mampu menampilkan sikap dan pribadi yang sesuai dengan harapan peserta didik. Kualitas pribadi konselor adalah instrumen yang sangat berpengaruh dalam proses konseling. Hubungan interpersonal yang terjalin dalam sesi konseling merupakan motor penggerak keberhasilan layanan. Hal ini dikarenakan hubungan yang dibangun antara konselor dan peserta didik atau disebut proses terapeutik konseling merupakan faktor yang utama dan sangat menentukan keberhasilan pencapaian tujuan konseling[17]. Konselor yang rendah hati dan bernuansa spiritual atau religius serta fleksibilitas tempat dalam melakukan layanan dapat juga menjadi indikator kenyamanan dalam melakukan pelayanan [18].

\section{KESIMPULAN DAN SARAN}

Permasalahan terkait kompetensi profesional konselor adalah kemampuan berpikir ilmiah, sistematis dan komprehensif dalam memahami permasalahan peserta didik, menjalankan prosedur dan teknik konseling yang sesuai, serta merancang program konseling dan evaluasinya serta riset mengenai proses konseling yang dilakukan. Selain itu, peermasalahan peserta didik di era digital juga cukup banyak sehingga menjadi tantangan bagi konselor dalam mengembangkan layanan BK yang sesuai. Hal ini akan menjadi upaya yang cukup panjang dalam mengatasinya, mengingat salah satu kelemahan konselor justru dalam mengimplementasikan konsep bimbingan konseling yang sesuai dengan kondisi di lapangan.

Konselor sepertinya lebih banyak menggunakan pengetahuan yang ada di buku teks dengan kurang mempertimbangkan relevansinya dengan perubahan yang terjadi. Selain itu, konselor harus memiliki kemampuan menggunakan teknologi informasi dan memanfaatkannya untuk melakukan pelayanan yang lebih optimal terhadap generasi peserta didik di era digital ini.

\section{DAFTAR PUSTAKA}

[1] Ditjen PMPTK (2008). Bimbingan Konseling di Sekolah, www.file.upi.edu. Hal.7

[2] ABKIN. (2006) Kode Etik Profesi Konseling. www.konselor.org. Hal. 1.

[3] Suherman, U. (2007). Kompetensi dan Aspek Etik Profesional Konselor Masa Depan. Educationist, Vol 1 No 1 Hal. 39-47.

[4] Gudnanto, Kiswantoro. A., dan Zamroni, E. (2013). Kompetensi Konselor dalam Kurikulum 2013. Prosiding Seminar Dan Workshop 
Nasional "Mengupas Implementasi Kurikulum 2013 Bimbingan dan Konseling Dalam Praktik"

[5] Ramadhoni, S. R., dan Bulantika, S. Z.. (2020). Kompetensi Multikultural bagi Konselor Sekolah. Journal of Guidance and Counseling Inspiration. Vol. 1 No. 1 Hal. 19-30

[6] Fatmawijaya, H. A. (2015). Studi Deskriptif Kompetensi Kepribadian Konselor yang Diharapkan Siswa. PSIKOPEDAGOGIA. Vol. 4, No.2 Hal. 124-135

[7] Laporan Hasil Uji Kompetensi Guru SMA dan SMK DKI Jakarta Tahun 2005. Penelitian. Dinas Pendidikan Menengah dan Tinggi DKI Jakarta. Tidak diterbitkan.

[8] Nurahmi, H., (2015). Kompetensi Profesional Guru Bimbingan dan Konseling. Hal. 45-50. https://core.ac.uk

[9] Anderson, E. L., Steen, E., and Stavropoulos, V. (2016). Internet use and Problematic Internet Use: a systematic review of longitudinal research trends in adolescence and emergent adulthood. International Journal of Adolescence and Youth, 22(4), 430-454.

[10] Sholihah, I. N, Handayani, T., Baskoro, B. T. (2018). Profesionalisme Konselor Sekolah dalam Pelayanan Generasi Milenial. Prosiding Seminar Nasional BK 2018. Hal. 28-32

[11] Firman. (2018). Pendekatan Konseling Sebaya Tepat Guna untuk Generasi Milenial dalam Perubahan Sosial Budaya.

[12] APA. (2018). Stress in America: Generation Z. Stress in America.

[13] Webster, D., Dunne, L., \& Hunter, R. (2020). Association Between Social Networks and Subjective Well-Being in Adolescents: A Systematic Review. Youth \& Society, 0044118X20919589. https://doi.org/10.1177/0044118X20919589

[14] Halim, N. A.. Penggunaan Media Internet Di Kalangan Remaja Untuk Mengembangkan Pemahaman Keislaman. Jurnal Risalah, Vol. 26, No. 3, September 2015: 132-150

[15] Kurniawan, K.. (2013). Perubahan Pola Pikir Basis Implementasi Kompetensi Konselor. Jurnal Konseling dan Pendidikan. Volume 1 Nomor 1. Hal. 10-14.

[16] Kirana, D. L.. (2019). Cyber Counseling Sebagai Salah Satu Model Perkembangan Konseling Bagi Generasi Milenial. al-Tazkiah, Volume 8 No. 1 Hal. 51-63

[17] Putri, A. (2016). Pentingnya Kualitas Pribadi Konselor dalam Konseling untuk Membangun Hubungan antar Konselor dan Konseli. Jurnal Bimbingan Konseling Indonesia Volume 1 Nomor 1. Hal. 10-13

[18] Sumerlin, T. (2011). The Heart of the School Counselor: Understanding Passion over the Span of a Career. Professional School Counseling Vol 14 No 4 Hal. 278-285 